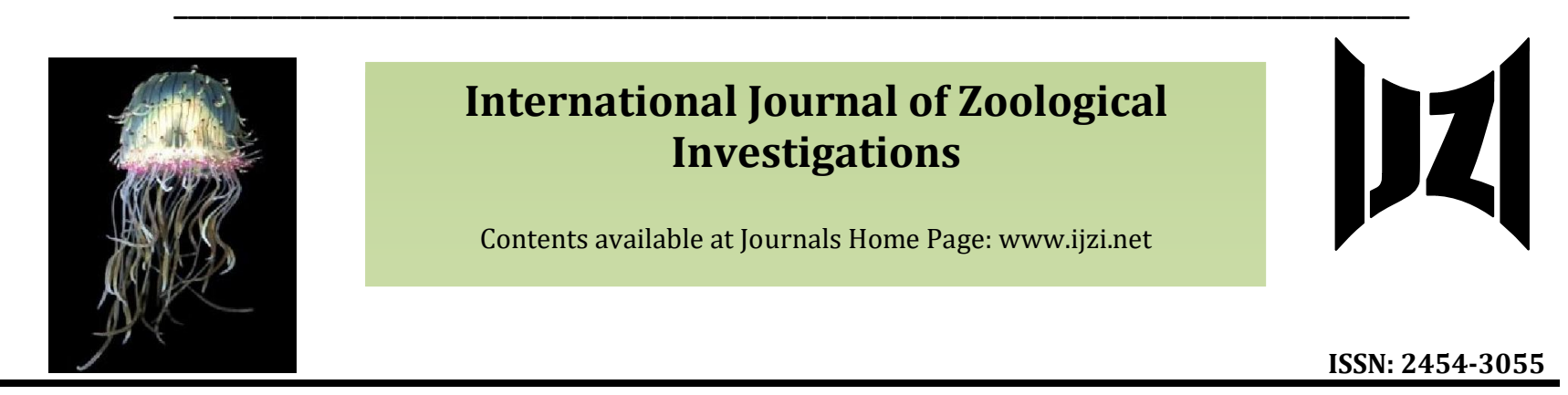

\title{
Condition Factor of Fishes of Rapti River in Different Seasons at Balrampur, Uttar Pradesh, India
}

\author{
Verma Dharmraj ${ }^{\text {1* }}$, Ahmad Tabrez ${ }^{2}$, Bajpai Sandeep ${ }^{3}$, Dixit Vivek Kumar ${ }^{4}$ and Singh U.B. ${ }^{1}$ \\ 1Department of Zoology, P.B PG College, Pratapgarh U.P., India \\ 2Department of Zoology, BSNV PG College Lucknow U.P., India \\ ${ }^{3}$ Department of Zoology, BVB Girls Degree College Lucknow, U.P., India \\ ${ }^{4}$ Department of Zoology, University of Lucknow, Lucknow, U.P., India \\ ${ }^{*}$ Corresponding Author
}

Received: $28^{\text {th }}$ November, 2019

Accepted: 24th December, 2019

https://doi.org/10.33745/ijzi.2019.v05i02.010

Abstract: The study appraised the condition factor of 35 species of fish from Rapti river. A total of 35 fish species were collected (belonging to 26 genera, 17 families and 7 orders) with the help of local fishermen using different fishing gears and nets from January 2016 to December 2017. The condition factor is an important biological parameters which indicates the suitability of a specific water body for growth of fish and an index of species average size. The condition factor of Anabas testudineus was found higher (10.214 in summer, 13.132 in rainy, 14.590 in winter) whereas condition factor of Bagarius bagarius was lowest (0.0311 in summer, 0.0380 in rainy, 0.0391 in winter).Results of the study revealed about the condition of the fish species throughout the year. Indiscriminate catch using fine mesh size nets, dumping of sewage, siltation, changing land use pattern, decreased water discharge and exotic species are the major threat for fish species and their habitat. An extensive study on the actual number of fishermen and their socio-economic condition is required to evaluate the actual production. The results of the present study will play significant role in the management of fish culture programmes as well as protection of their natural habitats.

Keywords: Rapti river, Condition factor, Fish fauna, Socio-economic status

Citation: Verma Dharmraj, Ahmad Tabrez, Bajpai Sandeep, Dixit Vivek Kumar and Singh U.B.: Condition Factor of Fishes of Rapti River in Different Seasons at Balrampur, Uttar Pradesh, India. Intern. J. Zool. Invest. 5 (2): 118-128, 2019.

$\underline{\text { https://doi.org/10.33745/ijzi.2019.v05i02.010 }}$ 


\section{Introduction}

Water is the basic necessity for the survival of life and prosperity of civilization. It covers three fourth of Earth's surface and comprises about two-third of most of the organisms. Today, the problem of water scarcity is of great concern in the rural as well as urban areas. Rivers are the principal sources of freshwater for living creatures. Anthropogenic activities, urbanization, land reclamation and accelerated industrialization prone to majority of lotic and lentic water bodies more and more deteriorated/polluted. Rivers, the major sources of irrigation are used as depositories for disposal of domestic sewage, industrial effluents containing toxic substances and heavy metals, agricultural runoff etc. They are non-degradable and often accumulate through trophic level causing a deleterious biological effect. Though water pollution is an old phenomenon, the rate of industrialization and consequently, urbanization has exacerbated its effect on the environment. This is because, the process of urbanization has considerable hydrological impact both in terms of controlling rate of erosion, delivery of pollutants to rivers, and in terms of influencing the nature of runoff and other hydrological characteristics (Asonye et al., 2007).

Rivers are vital and vulnerable freshwater systems that are critical for the sustenance of all life. The maintenance of healthy aquatic ecosystem is depended on the physicochemical properties and biological diversity. A regular monitoring of water bodies with required number of parameters with reference to the quality of water not only prevents the outbreak of diseases and occurrence of hazards but checks the water from further deterioration. Bacteriological assessment, particularly for coliforms the indicators of contamination by faecal matters is therefore routinely carried out to ascertain the quality and potability of water to ensure prevention of further dissemination of pathogens through agency of water under investigation (Venkatesharaju et al., 2010).

India is gifted with a river system comprising more than 20 major rivers with several tributaries (Kumar et al., 2005), and more than $50 \%$ of water resources of India are located in various tributaries of these river systems (Lal, 2001). Biodiversity refers to the totality of genes, species and ecosystems of a region. The fish diversity is subjected to the changes in land and water resulting into substantial losses of fishes and remaining species may be at a risk.

Fishes are the keystone species which determine the distribution and abundance of other organisms in the ecosystem they represent and are good indicators of the water quality and the health of the ecosystem. Nearly $20 \%$ of the world's freshwater fish fauna is already extinct or is on the verge of extinction (Ali, 2010).

Condition factor $(\mathrm{K})$ of fish species is very important parameter for understanding fish biology and pathology (Abujam and Biswas, 2014). Fishery is one of the most important branches for food production globally and need for understanding fish biology and their health status. Fish represents an important resource which can be used as food for the human populations' worldwide (Fagbuaro et al.,2019). Condition factor can be used as good indicator of water quality or general health of fish populations which are inhabiting specific habitat or ecosystem (Izah and Srivastav, 
2015). The value of $\mathrm{K}$ is calculated from the weight and length and can be used to estimate changes in nutritional condition (Froese, 2006).

River Rapti is a tributary of Ganga river system. It is one of the main rivers of the tarai region of Uttar Pradesh, India. It is originated from the southern hills of Himalaya near 'Rukum Kot', situated in the south of Dhaulagiri in sub-Himalayan series of Nepal. It travels $152 \mathrm{~km}$ in Nepal and enters in the eastern part of 'Kurva' village of Bahraich district between Charda (Bahraich) and Bhinga (Shravasti) then reaches to Ikauna region of Shravasti district. Later it enters in Balrampur district traversing Degrajot village through Ikauna. It flows about $640 \mathrm{~km}$ passing through Bahraich, Shravasti, Balrampur, Siddhrath Nagar, Basti and Gorakhpur districts where it finally merges into Ghaghra river. Its main tributaries are Bhakla, Ken, Burhi Rapti, Suranra, Kuwano, Visuhi and Suaon nallah. Suaon nallah is the main source of pollution to this river in Balrampur district because it receives sugar and distillery effluents of Balrampur Chini Mills Ltd, Balrampur.

This study appraised the condition factor of 35 fish species collected from Rapti river from Balrampur, Uttar Pradesh, India.

\section{Materials and Methods}

Topography of the Area:

The study area, Balrampur, is situated in North Terai region of Uttar Pradesh adjacent to Indo-Nepal border at $27^{\circ} 16^{\prime} \mathrm{N}$ to $27^{\circ} 32^{\prime}$ North altitude and $82^{\circ} 03^{\prime} \mathrm{E}$ to $82^{\circ} 22^{\prime}$ East longitude and an altitude of about 113 meters above the mean sea level. Rapti is the main river traversing in the area and plays a vital role in the topography and causes serious flood havoc in the rainy season. The slope of the area is from north-west to south-east. Sugarcane is one of the major crops of the district which requires large amount of water. There are three sugar factories, Balrampur Chini Mills, Bajaj Chini Mills and Tulsipur Chini Mills, situated at about $5 \mathrm{~km}, 18 \mathrm{~km}$ and $30 \mathrm{~km}$ away from Balrampur city, respectively.

The district Balrampur lies between Nepal in the north and district Gonda in the south. Its eastern and western boundaries are common with Siddharthanagar and Shravasti districts, respectively (Figs. 1, 2).

\section{Meteorology of the Study Area:}

A climatological data i.e. temperature and rainfall data for the period of January 2008 to December 2009 were obtained from Department of Climate, Government of India, situated near Rapti Bridge at Balrampur.

The climate of the study area is hot and dry in summer, mild and free from frost in cold season. The monsoon commences from the second week of June and continues till mid-October. July and August are months of maximum rain-fall (In July 2008, rain fall was as much as $538.1 \mathrm{~mm}$ and in August 2008, rainfall was $396.5 \mathrm{~mm}$ ). About $90 \%$ of the annual rainfall is obtained during the monsoon months.

The monthly average of minimum temperature ranged between 4.0 to $26.5 \mathrm{C}$ and that of maximum temperature between 21.8 to 37.5 C. During the study period maximum temperature was recorded in June and minimum in January. 


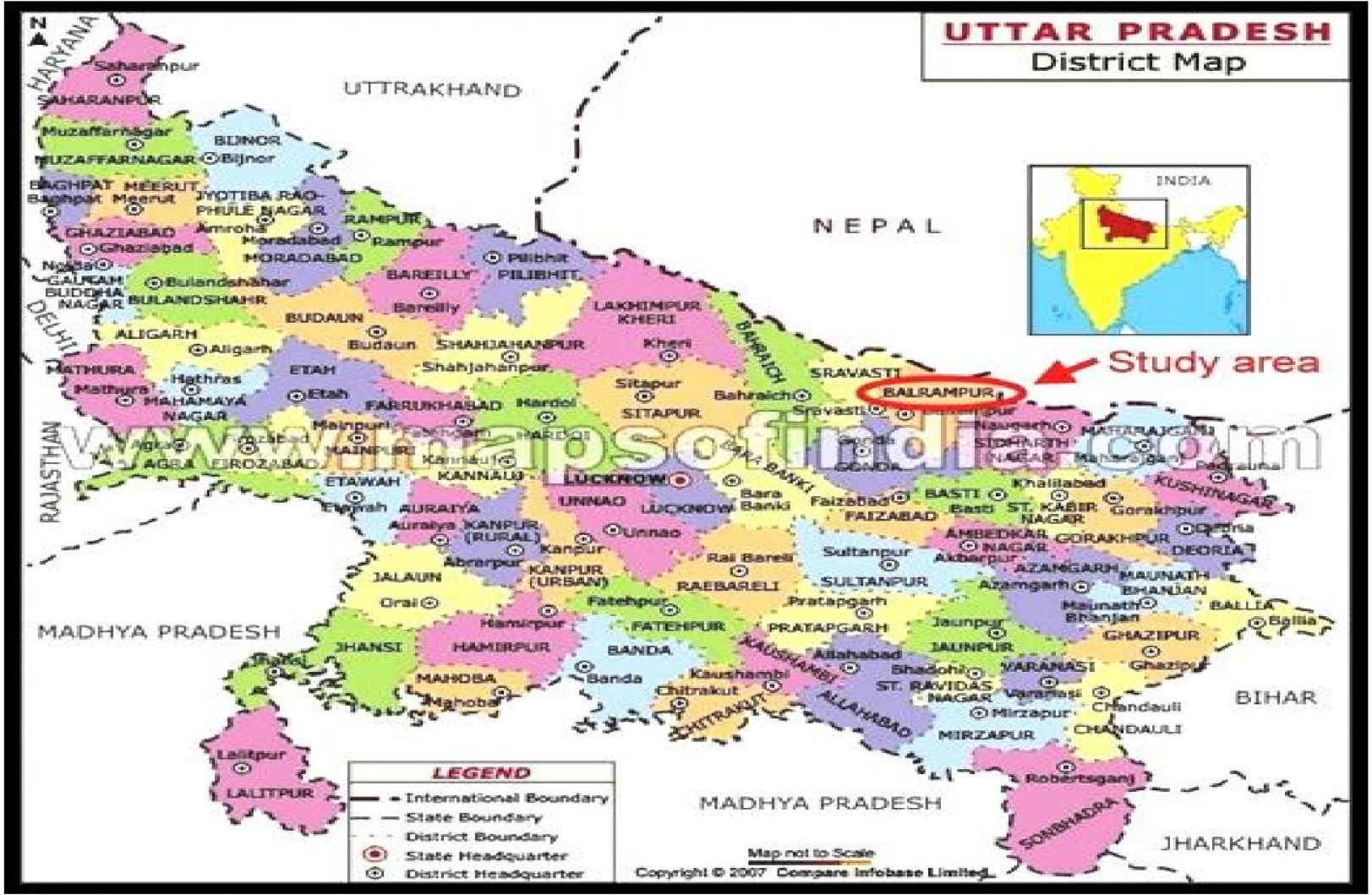

Fig. 1: Location of study area in Uttar Pradesh

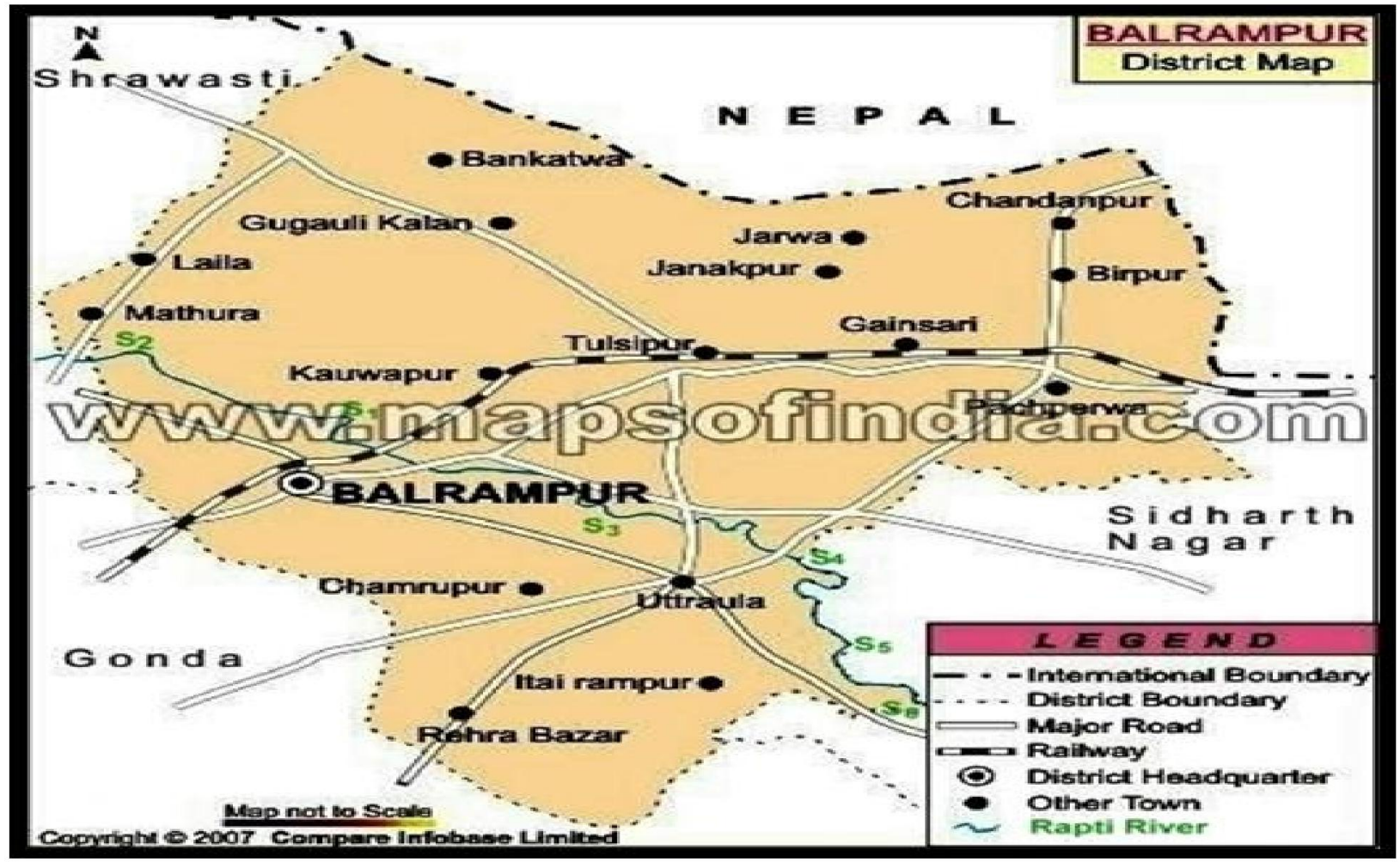

Fig. 2: Map of Balrampur district showing location of study sites of Rapti river 
Sampling Sites of Rapti River:

Site 1(Kodhari Ghat):

It is an upsterm of Rapti river. This station is located about $11 \mathrm{~km}$ away from Balrampur Rapti Bridge. Several human activities like idol dispersion, bathing, swimming and drinking by cattle are regular phenomenon of this site (Fig. 3.1).

Site 2 (Mathura Ghat):

It is an upstream station of Rapti river at the outskirt of the city. This station is approximately $21 \mathrm{~km}$ away from Balrampur Rapti bridge and about $10 \mathrm{~km}$ away from Kodhari ghat. A large number of activities presented at this site such as idol dispersion, bathing, washing, boating by human beings, domestic animals, cremation of dead bodies etc. (Fig. 3.2).

Site 3 (Sisai Ghat):

It is downstream station of Rapti river. This station is located from $5.6 \mathrm{~km}$ away from the Balrampur Rapti Bridge. Several activities like idol dispersion, cremation of dead body, and drinking of water both by animal and human beings are regular phenomenon of this station. In this station flood control center is situated (Fig. 3.3).

Site 4 (Mirzapur Ghat):

This is downstream station of Rapti River. It is situated about $12 \mathrm{~km}$ away from above station. Discharge of Suvaon Nallah which receives effluents of Sugar Factory and Distillery cause blackening of water in this station (Fig. 3.4).

Site 5 (Khamaria Ghat):

This station is situated near Utraula and approximately $15 \mathrm{~km}$ away from Mirzapur ghat. Idol dispersion, bathing, cremation are regular activity of this station (Fig. 3.5).

Site 6 (Pipra Ghat):

This station is situated about $28 \mathrm{~km}$ away from Khamaria ghat. Idol dispersion, cremation, swimming, washing of clothes, bathing by men and domestic animals are regular activities of this site (Fig. 3.6).

Identification of Fish Fauna:

Fishes were collected from time to time during netting and identified with the help of the book-Fauna of British India by Day (1878) and Fishes of U.P. and Bihar by Srivastava (1980).

\section{Condition Factor or Ponderal Index:}

The condition factor $(\mathrm{K})$ of the experimental fish was estimated from the relationship:

$$
\mathrm{K}=\frac{\mathrm{W} \times 100}{\mathrm{~L}^{3}}
$$

Where ' $\mathrm{K}$ ' is condition factor, ' $\mathrm{W}$ ' is weight in $\mathrm{g}$ and ' $\mathrm{L}$ ' is standard length in $\mathrm{cm}$. Higher value of ' $K$ ' means greater plumpness and well being of the fish and lower value means that fish are lean, thin and in poor condition which may be a reflection of either overpopulation, an outbreak of disease, pollution, scarcity of suitable food and stress etc.

\section{Results and Discussion}

For the exploitation and scientific development of aquaculture, knowledge of existing fish fauna of the area is a prerequisite. Knowledge of fish diversity in particular region is essential not only for rational management of ichthyofauna of that region but also for their conservation strategies. Biodiversity is a term that has recently been widely used all over the world. It is the variety 


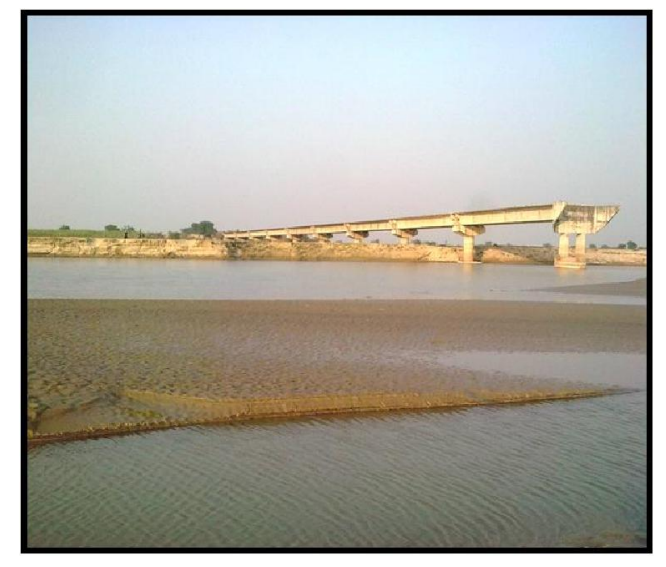

Fig. 3.1: Kodhari Ghat

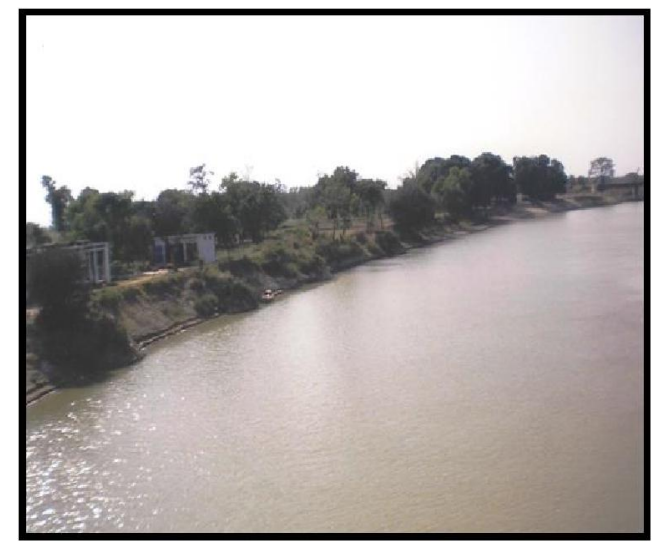

Fig. 3.3: Sisai Ghat

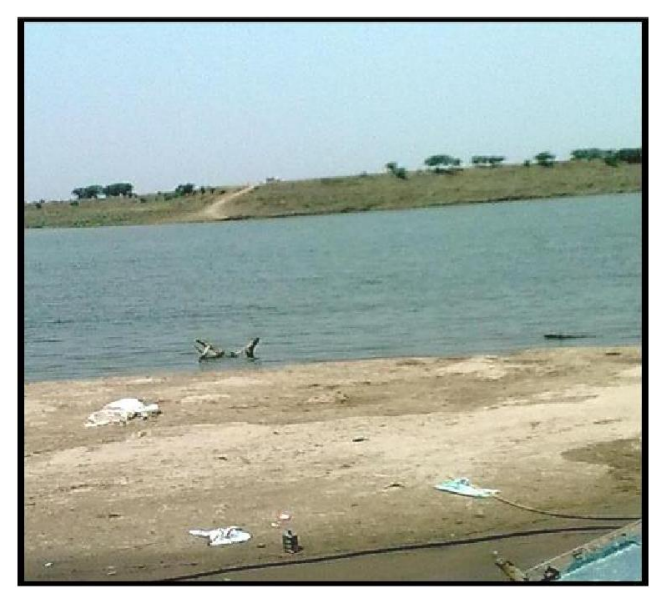

Fig. 3.5: Khamaria Ghat

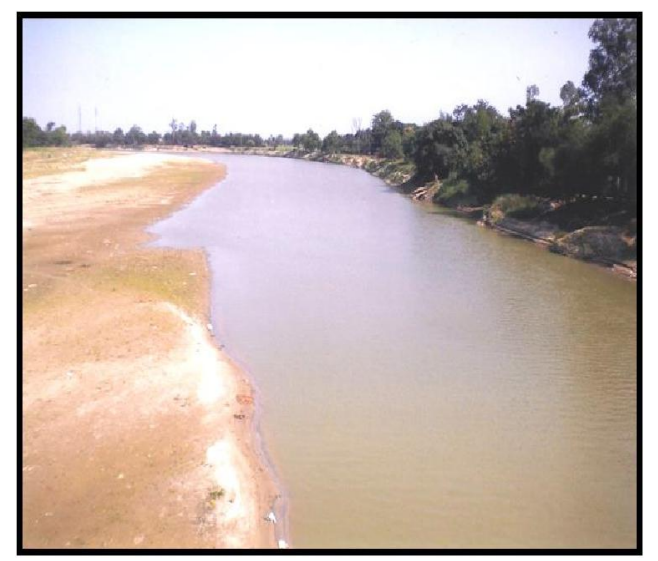

Fig. 3.2: Mathura Ghat

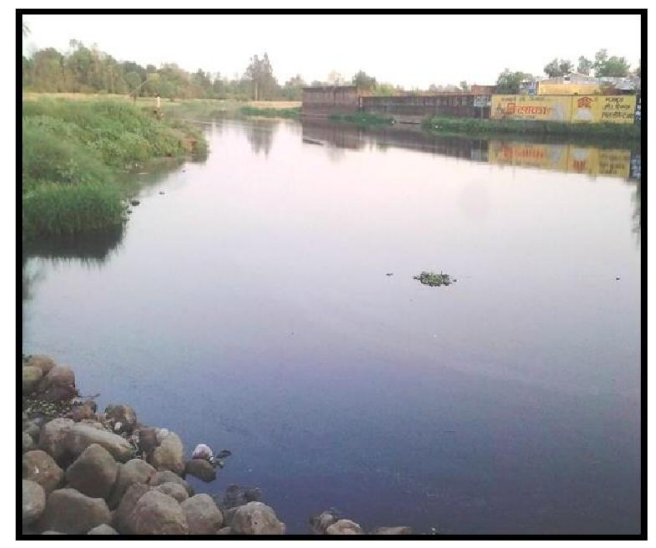

Fig. 3.4: Mirzapur Ghat

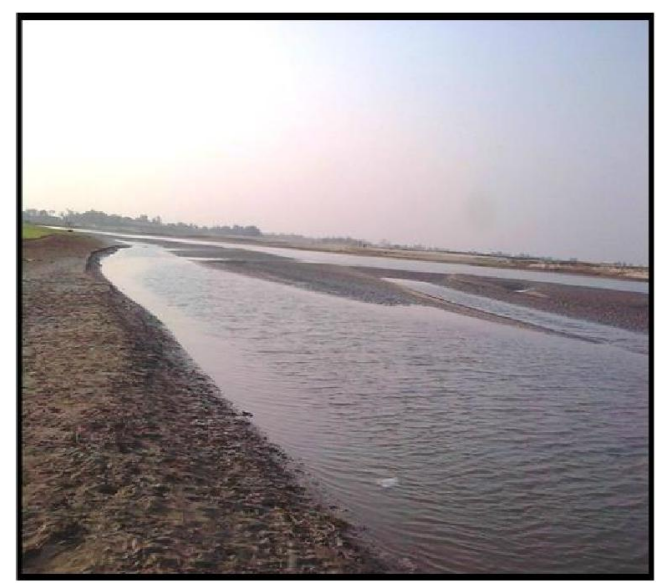

Fig. 3.6: Pipra Ghat

Fig. 3: Sampling sites

and variability among living organisms and the ecological complexes in which they occur. Diversity can be defined as the number of different organisms and their relative frequency. For biological diversity, these organisms are organized at many levels 
ranging from DNA sequences that are the molecular basis of heredity to complete ecosystem. Thus the term encompasses genes, species, ecosystems and their relative abundance. Biodiversity in inland waters is important not only to sustained health of the ecosystem but also to health and prosperity of our society. India is well known for rich biodiversity of biological wealth harbouring over $12 \%$ of the shell and fin fishes (Burman, 1998; Kapoor et al., 2002). Nelson (1984), however, stated only 21,723 fish species in the world. Day (1878) enlisted 1390 species of fish from British India. Jayaram (1994) and Talwar and Jhingran (1991) described 742 species from freshwater in India.

The family Cyprinidae contains maximum number of endemic fish (97 species), followed by the family Balitoridae (46 species) and the family Sisoridae (21 species) in India. Although a large number of workers have studied Ichthyofauna of various rivers, but much information is still not available regarding fish diversity in different rivers of Uttar Pradesh. Srivastava (1980) documented fish diversity of Uttar Pradesh and Bihar and reported that 111 species were found in this area. Rao (2001) accounted 83 fish species in the upper Ganga (Rishikesh to Kanpur). Payne et al., (2004) described 30 to 56 fish species in the river Ganga at Allahabad (Uttar Pradesh) and Patna (Bihar).

\section{Condition factor:}

Fish plays an important role in the development of a nation indirectly. Apart from being a cheap source of highly nutritive protein, it also contains other essential nutrients required by the body (Sikoki and Otobotekere, 1999). The length-weight relationship of fish is an important fishery management tool. Its importance is pronounced in estimating the average weight at a given length group (Beyer, 1987) and in assessing the relative well being of a fish population (Bolger and Connoly, 1989).

In fisheries science, the condition factor is used in order to compare the "condition", "fitness" or wellbeing of fish. And it is based on the hypothesis that heavier fish of a particular length are in a better physiological condition (Bagenal, 1978). Condition factor is also a useful index for the monitoring of feeding intensity, age, growth rates in fish (Kachari et al., 2017). It is strongly influenced by both biotic and abiotic environmental conditions and can be used as an index to assess the status of the aquatic ecosystem in which fish live (Anene, 2005). Condition factor decreases with increase in length. It also influence the reproduction cycle in fishes (Abowei et al., 2009). Thus condition factor or ponderal index, or co-efficient of correlation expresses the condition of a fish, such as the degree of well being, relative robustness, and plumpness of fatness in numerical terms (Mortuza and Rahman, 2006). It is influenced by number of factors such as seasons, fish length, sex and/or reproductive status of fish (Anene, 2005). Condition factor is not constant for a species or population over a time interval and might be influenced by both biotic and abiotic factors such as feeding regime and state of gonadal development (Saliu, 2001).

Vazzoler (1996) confirmed that lowest K values during the more developed gonadal stages might mean recourse transfer to the gonads during the reproductive period. Dakua et al. (2016) and others showed that values of the condition factor vary according to seasons 
Table 1: Condition factor of fishes of Rapti river in different seasons

\begin{tabular}{|c|c|c|c|}
\hline \multirow{2}{*}{ Zoological-Name } & \multicolumn{3}{|c|}{ Condition factor } \\
\hline & Summer & Rainy & Winter \\
\hline Notopterus notopterus (Pallas,1767) & 1.5214 & 1.8321 & 1.6222 \\
\hline Notopterrus chitala (Hamilton,1822) & 0.9831 & 1.4320 & 1.1320 \\
\hline Gudusia chapra (Hamilton, 1822) & 2.1621 & 1.9380 & 2.0610 \\
\hline $\begin{array}{l}\text { Setipinna phasa (Hamilton, 1822) } \\
\text { (18) }\end{array}$ & 2.0812 & 3.4121 & 3.0640 \\
\hline Cirrhinus mrigala (Hamilton, 1822) & 2.8014 & 3.4120 & 3.2592 \\
\hline Cirrhinus reba (Hamilton, 1822) & 3.8118 & 4.9141 & 4.8990 \\
\hline Labeo rohita (Hamilton, 1822) & 3.9281 & 4.1812 & 4.0509 \\
\hline Labeo calbasu (Hamilton, 1822) & 2.1210 & 2.3281 & 2.0480 \\
\hline Puntius sarana (Hamilton, 1822) & 5.8930 & 6.341 & 6.9613 \\
\hline Puntius sophore (Hamilton, 1822) & 1.9281 & 2.1412 & 2.3703 \\
\hline Catla catla (Hamilton, 1822) & 1.4121 & 1.8132 & 1.6692 \\
\hline Amblypharyngodon mola (Hamilton, 1822) & 2.321 & 4.002 & 3.4170 \\
\hline Oxygaster bacaila (Hamilton, 1822) & 2.1321 & 2.8140 & 2.551 \\
\hline Ompok bimaculatus (Bloch., 1797) & 2.1131 & 2.6321 & 2.5160 \\
\hline Wallago attu (Bloch. and Schneider, 1801) & 2.0121 & 2.4210 & 2.1040 \\
\hline Mystus cavasius (Hamilton, 1822) & 0.6113 & 0.6812 & 0.6726 \\
\hline Mystus vittatus (Bloch., 1797) & 0.3821 & 0.6321 & 0.5091 \\
\hline Mytus tengara (Hamilton, 1822) & 0.3214 & 0.5618 & 0.4688 \\
\hline Rita rita (Hamilton, 1822) & 2.9810 & 3.9281 & 3.4140 \\
\hline Bagarius bagarius (Hamilton, 1822) & 0.0311 & 0.0380 & 0.0391 \\
\hline Ailia coila (Hamilton,1822) & 1.712 & 1.1321 & 1.765 \\
\hline Clupisoma garua (Hamilton, 1822) & 0.9821 & 0.9431 & 1.512 \\
\hline Heteropneustes fossilis (Bloch.,1785) & 4.5121 & 4.1210 & 5.820 \\
\hline Clarias batrachus (Linn., 1758) & 7.1832 & 9.1021 & 8.1050 \\
\hline Xenentodon cancila (Hamilton,1822) & 3.8321 & 4.3121 & 4.6320 \\
\hline Rhinomugil corsula (Hamilton,1822) & 2.1321 & 2.8932 & 2.323 \\
\hline Channa punctatus (Bloch., 1785) & 1.0731 & 2.7301 & 1.8013 \\
\hline Channa striatus (Bloch., 1785) & 1.6213 & 1.9132 & 1.7089 \\
\hline Chanda nama (Hamilton, 1822) & 9.8210 & 11.3121 & 10.270 \\
\hline Chanda ranga (Hamilton, 1822) & 7.1380 & 9.3210 & 8.123 \\
\hline Badis badis (Hamilton, 1822) & 8.3210 & 9.8921 & 9.680 \\
\hline Anabas testudineus (Bloch., 1785) & 10.214 & 13.132 & 14.590 \\
\hline Colisa fasciatus (Bloch. \& Schn. 1801) & 10.2110 & 11.312 & 12.86 \\
\hline Macrognathus aculeatus (Bloch., 1787) & 3.9281 & 3.3214 & 4.935 \\
\hline Mastacembelus armatus (Lacepede, 1800) & 7.3210 & 7.9421 & 8.341 \\
\hline
\end{tabular}


and are influenced by environmental conditions. The same may be occurring in the environment under study since the flood plan is influenced by many biotic and abiotic factors, which favour the equilibrium of all the species in the ecosystem.

According to Sinha et al. (2018) all nonmigratory fishes show normal allometric growth and hence the fishes are in good condition. In the field of fishery science, condition factor or $\mathrm{K}$ is used to know the condition of fitness and wellbeing of fishes. The value of $\mathrm{K}$ is important for life cycle of fish species, thus contributing to the management of the species and equilibrium of aquatic ecosystem (Kumolu-Johnson and Ndimele, 2010). According to Barnham and Baxter (1998), condition factor is strongly influenced by both biotic and abiotic environment to assess the status of aquatic ecosystem in which the fishes lives.

The value obtained from the study showed that carnivorous fishes (Anabas testudineus, Colisa fasciatus, Chanda nama, Badis badis, Mastacembelus armatus and Chanda ranga) have high value of ' $K$ ' followed by Herbivorous fishes (Puntius sarana and Labeo rohita), detrivores fishes( Cirrhinus mrigala and Cirrhinus reba) and omnivorous fishes (Gudusia chapra, Oxygaster beacaila etc.) (Table 1). Higher value of ' $\mathrm{K}$ ' means greater plumpness and well being of the fish and lower value means that fish are lean, thin and in poor condition which may be a reflection of either overpopulation, an outbreak of disease, pollution, scarcity of suitable food and stress etc. Condition factor of fishes in different seasons revealed that winter season was good for the growth and development of fishes. The condition factor of Anabas testudineus was found higher (10.214 in summer, 13.132 in rainy, 14.590 in winter) whereas condition factor of Bagarius bagarius was lowest (0.0311 in summer, 0.0380 in rainy, 0.0391 in winter). Since in summer water temperature is optimal for growing and starts greatest feeding activity (Marcello De Giosa et al., 2014).The increased condition factor is due to fat deposition during the preceding growth season (Froese, 2006).

Gayando and Pauly (1997) reported that certain factors often affect the well-being of a fish. These include: Data pulling, sorting into classes, sex, stages of maturity and state of the stomach.

In discriminate catch, using of fine mesh sized nets, dumping of sewage, siltation, and water abstraction, changing land use pattern, decreased water discharge and exotic species threaten the fish diversity. Urgent need exist for taking research on the priority of fish species and their habitat.

\section{References}

Abowei JFN, Davies OA and Eli AA (2009) Study of the length-weight relationship and condition factor of fiver fish species from Nkoro river, Niger Delta, Nigeria. Curr. Res. J. Biol. Sci. 1: 94-98.

Abujam SKS. and Biswas SP. (2014) Length- weight relationship and condition factor of spiny eel Macrognathus aral from upper Assam, India. Intern. J. Current Life Sci. 4: 605-611.

Afamdi A. (2005) Condition factor for four cichlid species of a Man-made lake in Imo state, Southeastern Nigeria. Turkish J, Fisheries Aquatic Sci. 5: 43-47.

Ali H (2010) 'Studies on haematological and biochemical changes in food fishes of some water bodies of Balrampur due to the effects of common ecto- and endoparasites, Ph.D. Thesis, Dr. R.M.L. University, Faizabad, India.

Anene A. (2005) Condition factor of four Cichild species of a man-made Lake in Imo State South-eastern Nigeria. Turkish J. Fisheries Aqua. Sci. 5:43-47. 
Asonye CC, Okolie NP, Okenwa EE and Iwuanyanwu UG. (2007) Some physico-chemical characteristics and heavy metal profiles of Nigerian rivers, streams and waterways. African J. Biotech. 6: 617-624.

Bagenal TB. (1978) Aspects of fish fecundity. In: S.D. Gerking (Ed.) Ecology of freshwater fish production. Blackwell Scientific Publications, Oxford, pp.75-101.

Barnham PSM and Charles Baxter A. (1998) Condition factor 'Kn' for Salmonid fish. Fisheries Notes 5:1-3.

Beyer J E. (1987) On length-weight relationship. Part-I: Computing the mean weight of the fish of a given length class. Fishbyte 5: 11-13.

Bolger T and Connoly PL. (1989) The selection indices for the measurement and analysis of fish condition. J. Fish. Biol. 17: 1-182.

Burman RP. (1998) Zoological survey of India, Calcutta. 417-426.

Dakua S, Abujam SK, Islam M and Basumatary N. (2016) Length- weight relationship and condition factor of Parluciosoma daniconius (Hamilton) from upper Assam, India. J. Fisheries Sciences.com 10: 53-56.

Day F. (1878) The fishes of India being a natural history of the fishes known to in habit the seas and freshwater of India. Burma and Ceylon.Vol. I and II, p- XX+778, William Davson and Sons Ltd., London.

Fagbuaro 0, Ola-Oladimeji FA, Ekundare OV and Akinyemi 0. (2019) Length-weight relationship and condition factor of two species of Tilapia and one species of Mormyrops from a tropical dam in a Southwestern state, Nigeria. J. Zoological Res. 3: 1-5.

Froese R. (2006) Cube law, condition factor and weightlength relationships: history, meta-analysis and recommendations. J. Applied Ichthyol. 22: 241-253.

Gayando FC and Pauly D. (1997) FAO ICLARM stock assessment tools (FISAT): References Manual, FAO Computerized Information Series (Fisheries) 8: 262.

Giosa MD, Czerniejewaski P and Rbyczyk A. (2014) Seasonal changes in condition factor and weightlength relationship of invasive Carrassius gibelio (Bloch, 1782) from Leszczynskie Lakeland, Poland. Adv. Zoology. article ID 678763: 1-7.

Izah SC and Srivastav AL. (2015) Level of arsenic in potable water sources in Nigeria and their potential health impacts: A review. J. Environ. Treatment Tech. 3: 15-24.

Oni SK, Olayemi JY and Adegboye JD. (1983) The comparative physiology of three ecologically (Rupel). Synodonts schall Block and Schneider and Tilapia zilli (Gervais). J. Fish. Biol. 22: 105-109.
Jayaram, K. C. (1994). The freshwater fishes of India, Pakistan, Banglaesh, Burma and Sri Lanka-A Handbook. Zool. Surv. India. Publ. Kolkata.

Kachari A, Abujam S and Das DN. (2017) Lengthweight relationship (LWR) and condition factor of Amblyceps apangi Nath and Dey from Arunanchal Pradesh, India. J. Aqua. Eng. Fish. Res. 3:97-107.

Kapoor D. Dayal R and Ponnian AG. (2002) Fish biodiversity ofIndia. National Bureau of Fish Genetic Resources Lucknow, India, pp. 775.

Kumar R, Singh RD and Sharma KD. (2005) Water resources of India. Curr. Sci. 89: 794-811.

Kumolu-Johnson CA and Ndimele PE. (2010) Lengthweight relationships and condition factors of twenty-one fish species in Ologe Lagoon, Lagos, Nigeria - Asian J. Agricul. Sci. 2: 174-179.

Lal M. (2001) Climate change-Implications for India's water resources. J. India Water Res. Soc. 21: 101119.

Mortuza MG and Tawfeequa R. (2006) Length-weight relationship, condition factor and sex-ration of freshwater fish, Rhinomugil corsula (Hamilton) (Mugiliformes: Mugilidae) from Rajshahi, Bangladesh. J. Bio-Science 14: 139-141.

Nelson JS. (1984) Fishes of the World, 2nd Ed., John wiley and Sons., New Work. pp. 523.

Payne AI, Sinhua R, Singh HR and Huq S. (2004) A review of the Gangaes basin; its fish and fisheries. In: Welcome, R. L. and Petr, R. (eds.). Proceedings of the Second International Symposium on the Management of Large Rivers for Fisheries, Vol-1 Food and Agriculture Organization of the United Nations, Regional Office for Asia and the Pacific, Mekong River Commission (MRC), Fisheries Programme (FP), pp. 229-251.

Rao RJ. (2001) Biological resources of the Ganga river. Hydrobiologia 458: 159-168.

Reuben S, Vijaykumaran K and Cittibabu K. (1995) An example of fish production increase following greater protection of the coastal zone of eastern Ligunia. Biol. Mar. Mediterr. 3:222-229.

Saliu JK. (2001) Observation on the condition factor of Brycinus nurse (Pisces: Cypriniformes, Characidae) from Asa Reservoir, Ilorin, Nigeria. Tropical Freshwater Biology 10: 9-17.

Sikoki FD and Otobotekere AJT. (1999) Fisheries. In: The land people of bayelsa state central niger delta. E. C. Alagoa, (ed.). Port Harcourt, pp. 301-319.

Sinha AK, De P, Das A and Bhakat S. (2018) Studies on length-weight relationship, condition factors and 
length-weight relationship of Anguilla bengalensis bengalensis, Gray, 1831(Actinopterygii, Anguillidae) collected from river Mayurakshi, Siuri, Birbhum, West-Bengal, India. Intern. J. Fisheries Aqua. Studies 6: 521-527.

Srivastava GJ. (1980) Fishes of U. P. and Bihar. Vishwavidalaya Prakashan, Varanasi, U.P. India.

Talwar PK and Jhingran AG. (1991) Inland fishes of India and adjacent countries, Oxford and IBH Publishing Co., Pvt. Ltd. New Delhi, 2: 1158.
Vazzoler AEA. (1996) Biologia da reproducão de peixes Teleósteos: teoria prática. EBUEM, SBI, Maringá, pp. 169.

Venkatesharaju K, Ravikumar P, Somashekar RK and Prakash KL. (2010) Physicochemical and bacteriological investigation on the river Cauvery of kollegal stretch in stretch in Karnataka. Kathmandu University J. Sci. Eng. Tech. 6: 50-59. 